\title{
Indonesian andaliman fruit (Zanthoxylum acanthopodium DC.) extract supresses the expression of inflammatory mediators on fibroblasts cells in vitro
}

\author{
Shelly Lelyana' ${ }^{1}$ Armelia Sari Widyarman²*, Rahmi Amtha ${ }^{3}$ \\ 1 Department of Oral Medicine, Faculty of Dentistry, Maranatha Christian University, Bandung, Indonesia \\ 2 Department of Microbiology, Faculty of Dentistry, Trisakti University, Jakarta, Indonesia \\ 3 Department of Oral Medicine, Faculty of Dentistry, Trisakti University, Jakarta, Indonesia
}

\begin{abstract}
The recurrent aphthous stomatitis (RAS) is the oral mucosa inflammation that causes pain and interferes with daily activity. One of the RAS' predisposing factors is Streptococcus sanguinis infection, which causes an antigenic reaction. Ulcer progression in the oral cavity is modulated by tumor necrosis factor- $\alpha$ (TNF- $\alpha$ ) and interleukin-6 (IL-6). Zanthoxylum acanthopodium DC is known as andaliman is an Indonesian fruit that has been reported to have antimicrobial and anti-inflammatory activities. The objectives of this study were to analyze the cytotoxic concentration of andaliman fruit extract and determine the effect of andaliman fruit extract on TNF- $\alpha$ and IL-6 levels of fibroblasts infected with Streptococcus sanguinis. The cytotoxicity was determined by the 3-[4,5-dimethylthiazol-2yl]-2,5 diphenyltetrazolium (MTT) test. TNF- $\alpha$ and IL-6 levels were measured by enzyme-linked immunoassay (ELISA) tests. All the obtained data were statistically analyzed using the one-way analysis of variance (ANOVA) test ( $\alpha=0.05$ ). The MTT assays confirmed that $25 \mathrm{mg} / \mathrm{mL}$ concentration of $Z$. acanthopodium extract has no cytotoxic effects on fibroblast cells (viability=95.62\%). TNF- $\alpha$ and IL-6 level on infected fibroblast cells were significantly decreased $(P<0.05)$ after $25 \mathrm{mg} / \mathrm{mL}$ and $12.5 \mathrm{mg} / \mathrm{mL}$ concentration of $Z$. acanthopodium extract treatment, respectively. Our results concluded that Indonesian andaliman fruit significantly reduced the inflammatory biomarkers in the infected fibroblast cells. Furthermore, in vivo study using animal models is needed to confirm the anti-inflammatory potential of andaliman fruit extract.
\end{abstract}

\section{Keywords:}

Andaliman fruit, Anti-inflammation, Cytotoxicity, IL-6, TNF- $\alpha$, Zanthoxylum acanthopodium

\section{INTRODUCTION}

The recurrent aphthous stomatitis (RAS) is a common disease of the oral mucosa, manifested by recurrent mucosal ulcers ${ }^{1,2}$. The etiology of RAS is still unclear, but the predisposing factors include trauma, microbial infection, indigestion, blood disorders, emotional disorders (e.g., stress and worry), immunological disorders, nutritional deficiency, genetic disorders, allergy, and hormones (e.g., menstruation cycle) ${ }^{3,4}$. The etiopathogenetic basis is an inflammation due to Streptococcus sanguinis; this organism is one of the normal flora in the oral cavity but can cause an antigenic reaction and recurrent ulcers on the oral mucosa. Immunological changes are an underlying etiology of the oral mucosa inflammation, and the tumor necrosis factor $\alpha$ (TNF- $\alpha$ ) and interleukin-6 (IL-6) cytokines play a key role in ulcer progression of oral cavity ${ }^{4,5}$.

The primary strategy for RAS treatment is to control the inflammation, to suppress the inflammationassociated cells' activity, reducing the pain of the lesion, and accelerating the healing process $^{3}$. The most commonly used anti-inflammatory agents to treat oral cavity inflammations are topical corticosteroids ${ }^{6,7}$. However, the Indonesian government is currently promoting the use of herbal medicines as alternative treatments

*Corresponding author:

*Armelia Sari Widyarman armeliasari@trisakti.ac.id 
because Indonesia has many effective herbal plants, reasonably priced for its population. The Ministry of Health, Republic of Indonesia, now encourages the use and research of nutritious plants to reduce and treat illnesses, because these plants are easy to obtain and practical.

One promising alternative medicine is the andalimann (Zanthoxylum acanthopodium DC). The genus Zanthoxylum has known for its biological activities, including larvicidal, anti-inflammatory, analgesic, antioxidant, antibiotic, hepatoprotective, antiplasmodial, cytotoxic, antiproliferative, anthelmintic, antiviral, anticonvulsant, and antifungal properties. This plant is originated from North Sumatra, where it is known as intir-intir, but it is also known abroad as Sichuan pepper or Indonesian lemon pepper ${ }^{8,9}$. The $Z$. acanthopodium fruit is recognized for its chemical properties, such as $20.9 \%$ of oil, fat content, and the presence of terpenoids, flavonoids, limonene, and sabinene ${ }^{10}$.

A previous study showed that $Z$. acanthopodium pure essential oil created a $16 \mathrm{~mm}$ inhibition zone against Staphylococcus aureus and $12 \mathrm{~mm}$ when diluted to a $50 \%$ concentration ${ }^{11}$. The ethanol extract of $Z$. acanthopodium also had an antipyretic activity and suppressed the free radical activity by $61.81 \%$ at $200 \mathrm{ppm}$ concentration ${ }^{12}$. Therefore $Z$. acanthopodium extracts have the potential as food supplements and herbal medicines to treat inflammation, especially gastrointestinal inflammation ${ }^{13}$. There are many potential health benefits from $Z$. acanthopodium, but this plant extracts' effectiveness in reducing oral cavity inflammations like RAS has not been studied.

Any investigation into new medicines, whether natural or synthetic, requires strict safety tests on host cells and the establishment of any cytotoxicity effects. The cell viability quantification and cell proliferation tests are the basis for many in vitro safety studies ${ }^{14}$. However, no studies have been conducted to test the cytotoxicity of $Z$. acanthopodium extracts in fibroblasts, which are the key components of the oral mucosa and play an important protective role during the restoration of mucosa following a trauma event. Fibroblasts synthesize extracellular matrix and collagen that have important functions in epidermal proliferation and differentiation through the formation of cellular matrix and growth factors and cytokines secretion ${ }^{15,16}$. The present study aims to examine the cytotoxic effects of Z. acanthopodium ethanol extract on fibroblasts using the 3-[4,5-dimethylthiazol-2yl]-2,5 diphenyltetrazolium (MTT) assay method and determine the effects on TNF$\alpha$ and IL-6 levels in fibroblasts infected with S. sanguinis.

\section{MATERIALS AND METHODS}

This study was a laboratory experiment with a post-test only control design aimed to determine the cytotoxicity of $Z$. acanthopodium ethanol extract on fibroblasts and its effects on chemical anti-inflammation mediator's, TNF- $\alpha$, and IL- 6 levels in fibroblasts infected with $S$. sanguinis.

\subsection{Sample collection and extraction}

Zanthoxylum acanthopodium DC fruit originates from plantations in Parsoburan Habinsaran, Tobasa, North Sumatera, Indonesia, and was picked in young conditions with a characteristic of dark reddish-green color. The Parsoburan Habinsaran area is about 7001.650 meters above sea level. One kilogram of Zanthoxylum acanthopodium DC fruit was washed and dried at room temperature until completely dry. The dried Zanthoxylum acanthopodium DC fruit (267 grams) was ground and shifted until smooth. The simplicia was soaked in $70 \%$ ethanol inside a percolator overnight. Later, the ethanol was removed until the extract was obtained. Then $70 \%$ ethanol was added into the extract, filtered using a filter paper and the pulp was discarded. The ethanol was evaporated using an evaporator until the extract becomes thick. The extract was dried using the water bath method at $60-70^{\circ} \mathrm{C}$ and the obtained thick extract was ready to use. The thick extract of Zanthoxylum acanthopodium DC fruit was at $100 \%$ concentration. The dilution was performed using the $10 \%$ DMSO to obtain a series of concentration at $50 \%$, $25 \%, 12.5 \%$, and $6.25 \%{ }^{17}$.

\subsection{Qualitative phytochemical screening analysis}

Phytochemical analysis assay methods were done to determine the presence of bioactive compounds in the extracts. In this study, each phytochemical analysis assay was performed in The Indonesian Medicinal and Aromatic Crops Research Institute (local acronym BALITTRO), Bogor, Indonesia to detect the presence of saponins, tannin, alkaloids, phenolic compounds, flavonoids, triterpenoids, glycosides, and plant sterols from $Z$. acanthopodium ethanol extract. The saponins were identified by heating. The tannin and phenolic were analyzed by soaking the sample in the $\mathrm{FeCl}_{3} 1$ and 5\% solution, respectively. The alkaloids were detected using Dragendorff's and Mayer's reagent. The flavonoids were detected using $\mathrm{HCl}+\mathrm{Mg}$ and $\mathrm{NaOH}$ $10 \%$ solution. The triterpenoid and steroid were detected using $\mathrm{H}_{2} \mathrm{SO}_{4}+\mathrm{CH}_{3} \mathrm{COOH}$ solution. The qualitative results were expressed as (+) for the presence and (-) for the absence of phytochemicals.

\subsection{Streptococcus sanguinis culture}

The bacterial culture used in this study was obtained from the MiCore laboratory collection of the 
Faculty of Dentistry, Trisakti University, Jakarta. $S$. sanguinis was inoculated into the brain-heart infusion (BHI) broth (Thermo Scientific, Waltham, MA, USA) and incubated at $37^{\circ} \mathrm{C}$ in an anaerobic atmosphere. $S$. sanguinis was killed by heating at $80^{\circ} \mathrm{C}$ for $30 \mathrm{~min}$ before the exposure to the fibroblasts ${ }^{18}$.

\subsection{Fibroblast culture}

The fibroblast culture from the mouse was incubated at $37^{\circ} \mathrm{C}$ in a $5 \% \mathrm{CO}_{2}$ atmosphere for $24-72$ hours to allow the fibroblasts to mature into full fibroblast cells. The fibroblast growth was carried out at 3-4 days and the culture medium was changed regularly. A population of $10^{5}$ cells $/ \mathrm{mL}$ fibroblast cell was treated by the ethanol extract of $Z$. acanthopodium.

\subsection{Cytotoxicity evaluation using the 3-[4,5-dimethyl- thiazol-2yl]-2,5 diphenyltetrazolium (MTT) test}

3-[4,5-dimethylthiazol-2yl]-2,5 diphenyltetrazolium assay was performed by measuring the amount of violet formazan product generated by the reduction of the MTT tetrazolium dye by fibroblasts' mitochondrial dehydrogenase. Fibroblasts were added to the phosphatebuffered saline containing $1 \mathrm{mg} / \mathrm{mL}$ of MTT (SigmaAldrich, St. Louis, MO, USA) and incubated for three hours. The amount of formazan product was determined by measuring the absorbance at $490 \mathrm{~nm}$ with an AccuReader Microplate Reader (Metertech, Taipei, Taiwan). According to ISO 2010993-5-2009, regarding the biological evaluation of medical devices and in vitro cytotoxicity testing, it was determined if the cell viability showed less than $70 \%$ then the material has a toxicity potential.

\subsection{Enzyme-linked Immunoassay (ELISA) measure- ments of fibroblast's TNF- $\alpha$ and IL-6 levels}

The confluent fibroblasts $\left(10^{5}\right.$ cell $\left./ \mathrm{mL}\right)$ were exposed to $S$. sanguinis $\left(10^{7}\right.$ colony-forming units [CFU]/ $\mathrm{mL}$ )) for $24 \mathrm{~h}$ in a $5 \% \mathrm{CO}_{2}$ atmosphere at $37^{\circ} \mathrm{C}$ in 96 well-plate. The $Z$. acanthopodium ethanol extract was added and the fibroblasts were incubated for a further 24 hours. The TNF- $\alpha$ and IL-6 levels were determined using the ELISA method (BioLegend, San Diego, USA). The absorbance was measured at $490 \mathrm{~nm}$ with an AccuReader Microplate Reader (Metertech, Taipei, Taiwan). The ELISA assay was performed in triplicate. Wells without $Z$. acanthopodium ethanol extract was used as negative control and Triamcinolone $(0.01 \%)$ was used as a positive control. In this study, all procedures were triplicate.

\subsection{Statistical analysis}

The Shapiro-Wilk test was used for the normality test. One-way analysis of variance (ANOVA) test was applied to reveal the significant differences between TNF- $\alpha$ and IL-6 levels in the fibroblast cells infected with $S$. sanguinis and Zanthoxylum acanthopodium fruits extract in different concentrations. The differences were considered statistically significant if $P<0.05$. Statistical calculations were performed with SPSS Statistics for Windows software version 20 (IBM, USA).

\section{RESULTS}

\subsection{Preliminary phytochemical qualitative analysis of Zanthoxylum acanthopodium extract}

The use of spices in food has been practiced for centuries. The spices not only enhance the aroma and taste of the food but also provide health benefits. Apart from its unique flavor, several recent studies showed the various biological activities of these spices ${ }^{19}$. Zanthoxylum achanthopodium DC is one of the spices that commonly used as a seasoning in North Sumatran foods, especially by the Tapanulis. The genus Zanthoxylum belongs to the Rutaceae family. The plants in this genus are mainly used as spices and medicines. The name Zanthoxylum was created by Linnaeus in 1757 . This genus contains more than 546 species worldwide and 250 species were spread in tropical and subtropical regions of Asia and North America. Z. acanthopodium is one of the genera found in Indonesia ${ }^{20}$. The findings of this present study demonstrated that the Zanthoxylum acanthopodium fruits extract contained phenolic, tannin, flavonoid, triterpenoid, steroid, and alkaloid compounds (Table 1).

\subsection{Zanthoxylum acanthopodium extract did not affect fibroblast cell viability in a concentration of $25 \%$}

As shown in figure 1, the MTT assay showed that the fibroblast viability was $0.73 \%$ following the exposure to $100 \mathrm{mg} / \mathrm{mL}$ and $63.5 \%$ following the exposure to $50 \mathrm{mg} / \mathrm{mL} \mathrm{Z}$. acanthopodium ethanol extract. The fibroblast cell viability was much higher at $95.62 \%$, following the exposure to $25 \mathrm{mg} / \mathrm{mL} \mathrm{Z}$. acanthopodium extract.

\subsection{Zanthoxylum acanthopodium extract reduced TNF- $\alpha$ and IL-6 level on fibroblasts infected with S. sanguinis}

The TNF- $\alpha$ level was significantly decreased $(P<0.05)$ after $Z$. acanthopodium ethanol extract treatment in fibroblasts infected with $S$. sanguinis. The largest decrease in TNF- $\alpha$ level was obtained in the $50 \mathrm{mg} / \mathrm{mL}$ concentration, while $25 \mathrm{mg} / \mathrm{mL}$ concentration was almost 
Table 1. Phytochemical analysis result of Zanthoxylum acanthopodium extract.

\begin{tabular}{lc}
\hline Compound & Result \\
\hline Phenolic & + \\
\hline Tannins & + \\
\hline Flavonoids & + \\
\hline - HCl concentrated + Mg Reagent & + \\
- NaOH 10\% Reagent & - \\
\hline Saponins & + \\
\hline Triterpenoid & + \\
\hline Steroids & + \\
\hline Alkaloids & - \\
\hline - Dragendorff's Reagent & + \\
- Mayer's Reagent & \\
\hline
\end{tabular}

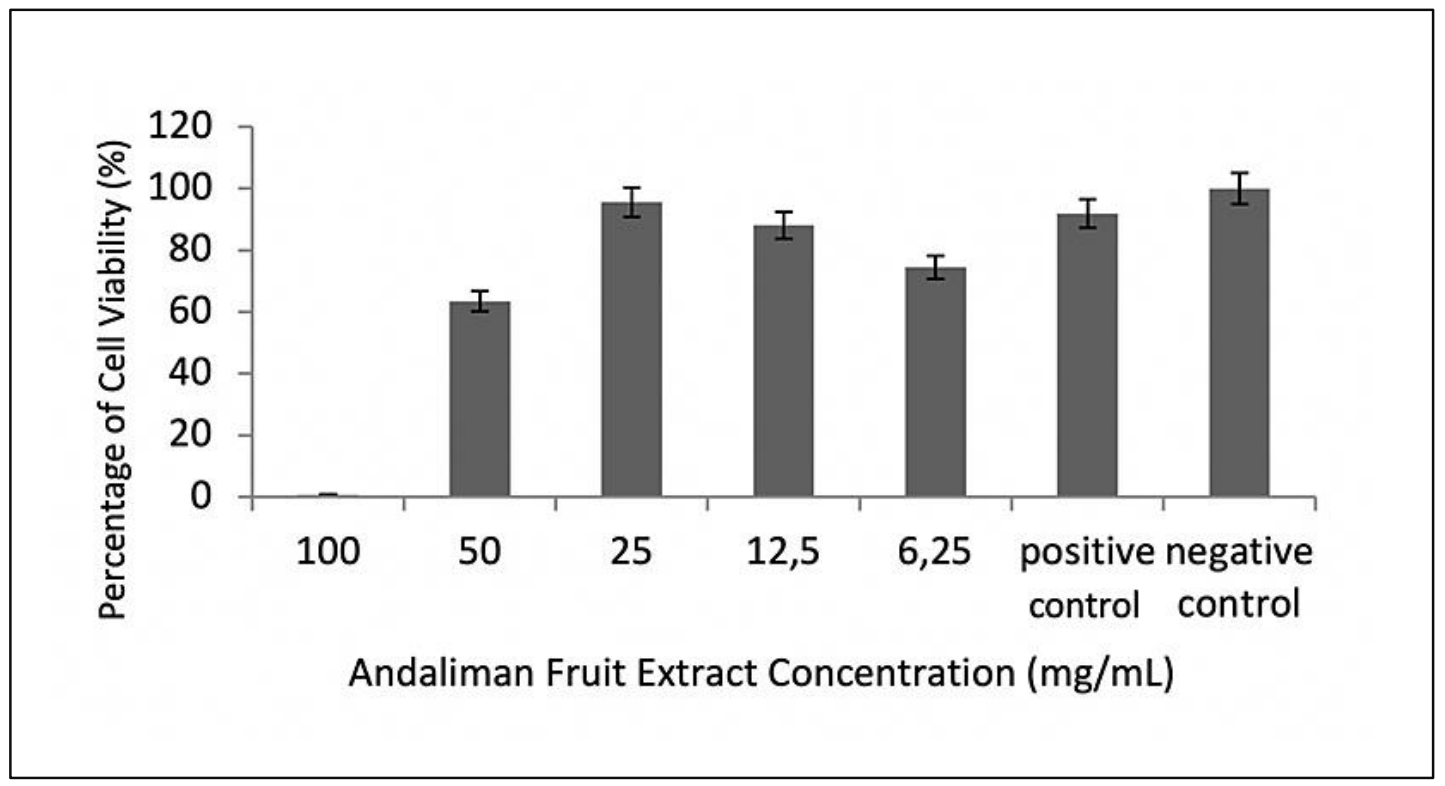

Figure 1. The viable fibroblast cells percentage after andaliman fruit (Zanthoxylum acanthopodium DC) extract treatment using MTT assay.

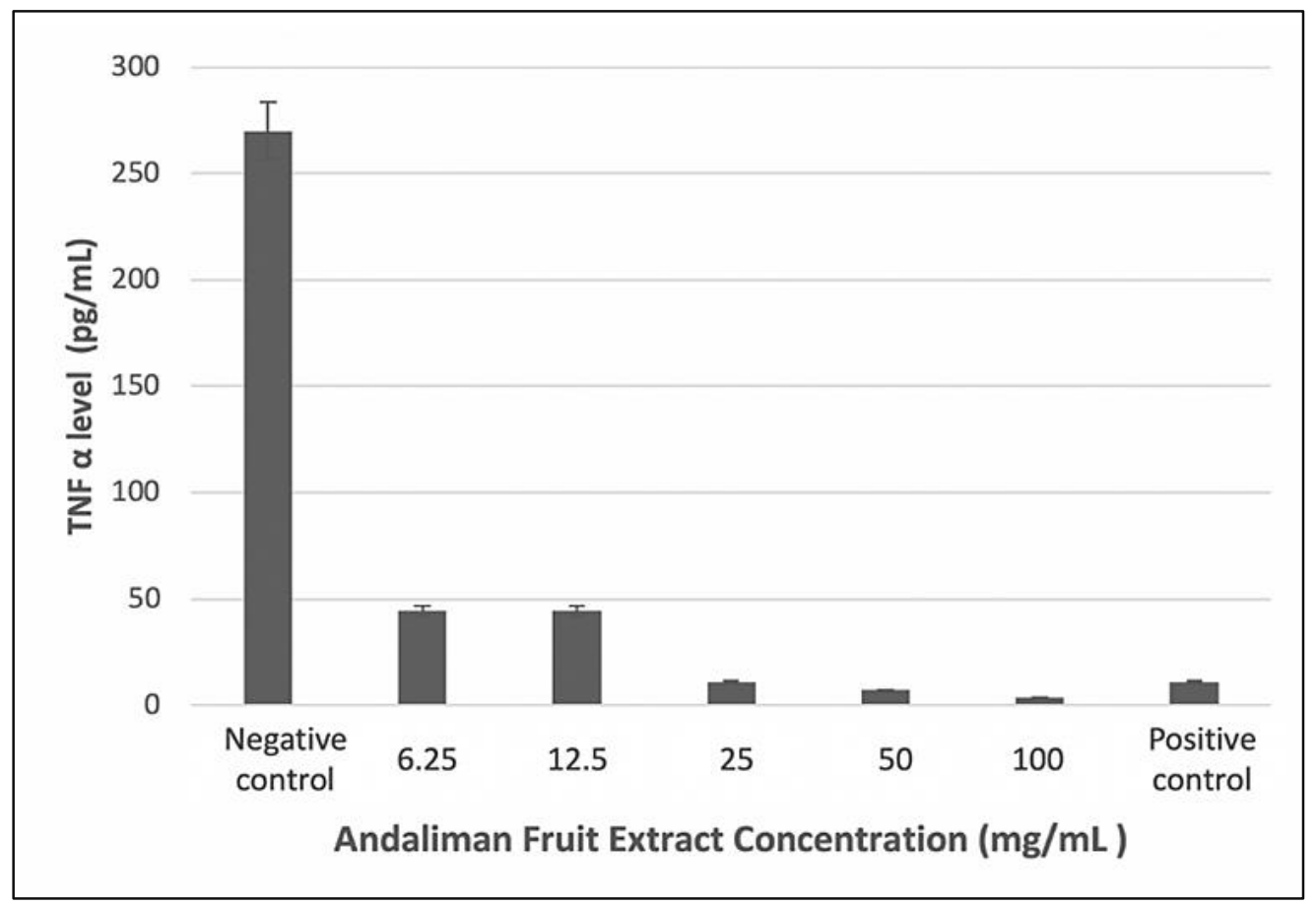

Figure 2. TNF- $\alpha$ level of $S$. sanguinis-infected fibroblast cells after treated with andaliman fruit (Zanthoxylum acanthopodium DC) extract. 


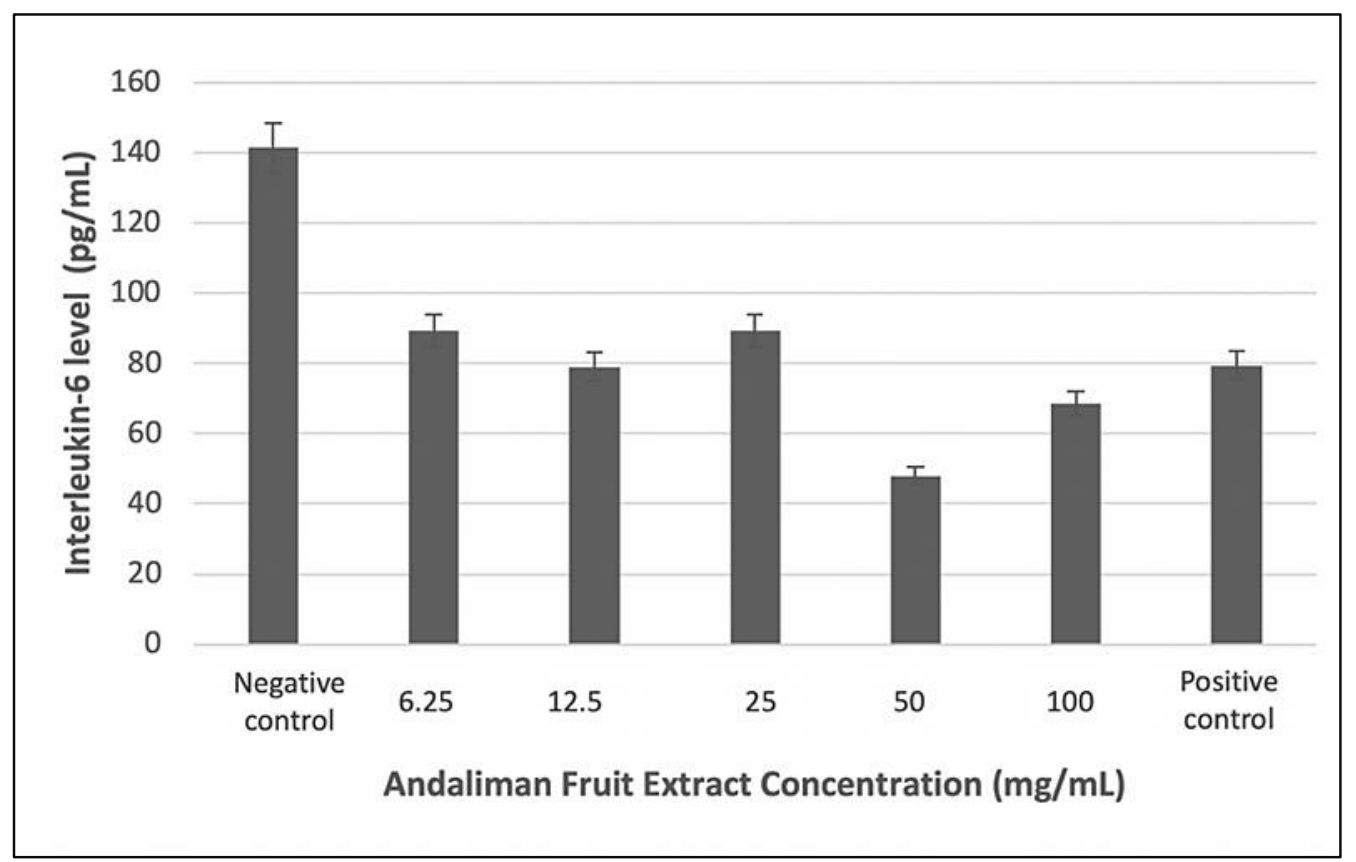

Figure 3. IL-6 level of infected fibroblast cells exposed to S. sanguinis after treated with andaliman fruit (Zanthoxylum acanthopodium DC) extract.

almost equivalent to triamcinolone positive control (Figure 2). The one-way ANOVA results confirmed the statistically significant differences $(P<0.05)$ in TNF- $\alpha$ level reduction of all concentrations compared to the negative control.

The IL-6 level was significantly decreased $(P<0.05)$ after the $Z$. acanthopodium ethanol extract treatment. The $50 \mathrm{mg} / \mathrm{mL}$ concentration greatly reduced the cytokine level compared to the other concentrations (Figure 3). The ANOVA test confirmed a significant difference $(P<0.05)$ in IL-6 reduction of all concentrations of $Z$. acanthopodium extract in fibroblasts infected with $S$. sanguinis compared to the negative control.

\section{DISCUSSION}

On cytotoxicity tests, the viable cells can reduce MTT to its colored formazan salt and the 490 $\mathrm{nm}$ measured absorbance is at parallels with the viable cell number, while dead cells are unable to change MTT into the colored formazan ${ }^{14}$. The cytotoxic agent exposure to cells causes toxicity through various mechanisms, such as membrane destruction, protein synthesis prevention, irreversible ligands attachment to receptors, DNA synthesis inhibition, and enzymatic reactions disruption. Cell necrosis is initiated upon the disruption of the cell's ability to maintain homeostasis, particularly water and ion homeostasis. Intracellular organelles, especially mitochondria and the cell will swell and rupture due to these disruptions, causing the release of cytoplasm, including the lysosome enzymes, into the extracellular fluid. The enzyme activity of the extracellular medium can be used to determine the necrosis level ${ }^{21,22}$.
Toxicity effects can be harmful or advantageous, depending on the ecological context and the pharmacology ${ }^{23}$. The ISO 2010993-5-2009 guidelines on the biological evaluation of medical equipment and in vitro cytotoxicity tests state that the potential toxicity is indicated by the cell viability measurements of less than $70 \%$. In the present study, the fibroblast viability was $0.73 \%$ for the $100 \mathrm{mg} / \mathrm{mL}$ concentration of $Z$. acanthopodium ethanol extract and more than $70 \%$ for the $25 \mathrm{mg} / \mathrm{mL}$. Therefore, $Z$. acanthopodium ethanol extract was toxic at $100 \mathrm{mg} / \mathrm{mL}$ concentration but nontoxic below $25 \mathrm{mg} / \mathrm{mL}$. A concentration of $25 \mathrm{mg} / \mathrm{mL}$ is likely a safe concentration of $Z$. acanthopodium extract as an oral anti-inflammatory agent. The previous study reported that the IC50 of the Zanthoxylum acanthopodium extract was $48.94 \pm 0.32 \mu \mathrm{g} / \mathrm{mL}$ to T47D breast cancer cell lines ${ }^{24}$. Different solvents might affect the cytotoxicity effect of the extract; Satria et al's study used ethyl acetate, while our study used ethanol as solvent ${ }^{24}$.

TNF- $\alpha$ and IL- 6 are cytokines associated with inflammation reactions. The secretion of TNF- $\alpha$ and IL-6 is stimulated by microbial products (e.g., bacterial endotoxins), immune complexes, and T-lymphocyte products that arise during the immune response ${ }^{25}$. In this study, Z. acanthopodium ethanol extract treatment resulted in a significant reduction in the TNF- $\alpha$ level of fibroblasts infected by $S$. sanguinis. The median effect of the $Z$. acanthopodium ethanol extract on the TNF- $\alpha$ level was significantly decreased with the increase of concentration. The $25 \mathrm{mg} / \mathrm{mL}$ concentration of $Z$. acanthopodium ethanol extract showed the potency as a promising anti-inflammatory agent because it decreased the TNF- $\alpha$ level close to positive control and 
was non-toxic to fibroblasts. The Z. acanthopodium extract significantly reduced the IL-6 levels in fibroblasts infected with $S$. sanguinis. The $25 \mathrm{mg} / \mathrm{mL}$ concentration of $Z$. acanthopodium extract was more effective and non-toxic at reducing the IL-6 levels than other concentrations. This suggests that $25 \mathrm{mg} / \mathrm{mL}$ concentration could be clinically useful as an antiinflammation treatment. IL-6 levels in each extract concentration did not have a specific trend or in a nondose response fashion. This condition may be caused by the function of IL- 6 which can be both pro and antiinflammatory cytokine. However, this hypothesis still needs further studies.

Oral mucosa healing is preceded by cell migration and proliferation. The process of extracellular protein matrix secretion is highly controlled and the matrix is extensively remodeled to rebuild injured tissue. Epithelial cells are the first cell to migrate to the center of a wound to prevent pathogen contamination. The fibroblasts then migrate to subepithelial areas and produce collagen and healing factors. The inflammation process is an important part of the healing process because the presence of inflammation modulators can delay the healing of oral mucosa ${ }^{26,27}$. A high concentration of inflammatory cytokines inhibits the migration of epithelial cells and fibroblasts and increases the TNF- $\alpha$ and IL- $1 \beta$ levels, thereby creating positive feedback for inflammation ${ }^{28}$.

In this study, the $Z$. acanthopodium extracts significantly reduce the inflammation mediator, TNF- $\alpha$ and IL- 6 , level. Therefore, the extract has the potential to serve as an anti-inflammatory agent and accelerate the healing process of the oral mucosa. The observed reduction of TNF- $\alpha$ and IL-6 levels in this study indicated that the $Z$. acanthopodium ethanol extract provided a greater reduction in TNF- $\alpha$ than in IL-6 cytokine levels. Therefore, this extract may be useful for controlling inflammation in the oral cavity, because TNF- $\alpha$ is a commonly found inflammation mediator in RAS cases.

Based on the phytochemical testing results, it can be seen that the ethanol extract of Zanthoxylum acanthopodium DC fruit in this study contains phenolic, tannin, flavonoid, triterpenoid, steroid, and alkaloid compounds. Flavonoid and tannin have potential benefits as an antioxidant and anti-inflammatory agents ${ }^{29,30}$. Flavonoids also have biochemical effects, which inhibit some enzymes, such as aldose reductase, xanthine oxidase, phosphodiesterase, $\mathrm{Ca}^{+2}$-ATPase, lipoxygenase, and cyclooxygenase. They have been found to have anti-inflammatory activity in both proliferative and exudative phases of inflammation ${ }^{29}$. This study observed the significant decrease of TNF- $\alpha$ and IL-6 levels as the effect of ethanol extract of Zanthoxylum acanthopodium DC on inflammation in fibroblasts infected with Streptococcus sanguinis.

\section{CONCLUSIONS}

Indonesian andaliman fruit (Zanthoxylum acanthopodium DC) ethanol extract was found to be non-toxic below the concentration of $25 \mathrm{mg} / \mathrm{mL}$. $Z$. acanthopodium as herbal plant has the efficacy as an anti-inflammatory in the oral cavity since it could decrease the level of TNF- $\alpha$ and IL-6 as chemical mediators. Indonesian andaliman fruit could be used as an herbal medicine to reduce inflammation, particularly within the oral mucosa. Further studies on molecular mechanisms on the Zanthoxylum acanthopodium substances to modulate the expression of inflammatory cytokines and proteins in fibroblast is still needed. Furthermore, in vivo study using an animal model is needed to confirm the anti-inflammatory potential of this herbal plant.

\section{ACKNOWLEDGEMENT}

Thank you to the Faculty of Dentistry of the Maranatha Christian University, Faculty of Dentistry of the University of Trisakti, and MiCore laboratories for supporting this study.

\section{Conflict of interest}

There are no conflicts of interest related to individual author's commitments or project support.

\section{Funding}

None to declare.

\section{Ethics approval}

None to declare.

\section{Article info:}

Received April 23, 2020

Received in revised form October 24, 2020

Accepted December 9, 2020

\section{Author contribution statement}

ASW, RA, SL conceived, and designed the study. ASW and SL conducted the laboratory experiments. ASW, RA, and SL analyzed the data. SL and ASW wrote the manuscript. All authors read and approved the manuscript.

\section{REFERENCES}

1. Bruch JM, Treister NS. Clinical oral medicine dan oral pathology. New York: Springer; 2010.

2. Chavan M, Jain H, Diwan N, Khedkar S, Shete A, Durkar S. Recurrent aphthous stomatitis: A review. J Oral Pathol Med. 2012;41(8):577-83.

3. Cawson RA, Odell EW. Disease of the oral mucosa: Noninfective stomatitis in oral pathology and oral medicine. London: Churchill Livingstone; 2002. p. 192-5.

4. Belenguer-Guallar I, Jimenez-Soriano Y, Claramunt-Lozano A. Treatment of recurrent aphthous stomatitis: A literature review. 
J Clin Exp Dent. 2014;6(2):e168-74.

5. Challacombe SJ, Alsahaf S, Tappuni A. Recurrent aphthous stomatitis: Towards evidence-based treatment?. Curr Oral Health Rep. 2015;2:158-67.

6. Greenberg MS, Glick M, Ship JA. Burket's Oral Medicine. Ontario: BC Decker Inc.; 2015. p. 81-252.

7. Scully C. Medical problems in dentistry. 6th ed. London: Churchill Livingstone; 2010. p. 439-40.

8. Kristanty RE, Suriawati J. The Indonesian Zanthoxylum acanthopodium DC.: Chemical and biological values. Int $\mathbf{J}$ PharmTech Res. 2015;8(6):313-21.

9. Negi JS, Bisht VK, Bhandari AK, Singh PK, Sundriyah RC. Chemical constituents and biological activities of the genus Zanthoxylum: A review. Afr J Pure Appl Chem. 2011;5:412-6.

10. Natasutedja AO, Lumbantobing E, Josephine E, Carol L, Junaedi D, Normasiwi S, et al, Botanical Aspects, Phytochemicals and Health Benefits of Andaliman (Zanthoxylum acanthopodium). IJLS. 2020;2(1):8-15.

11. Sukmiwati M, Sumarto S, Wirawan C. The effect of andaliman fruit (Zanthoxylum acanthopodium DC) on quality of smoked catfish (Pangasius hypophthalmus) stored at room temperature. Berkala Perikanan Terubuk. 2013;41(1):75-83.

12. Kristanty RE, Munim A, Katrin. Aktivitas antioksidan dan penghambat xantin oksidase dari ekstrak buah andaliman (Zanthoxylum acanthopodium DC). JFIOnline. 2013;6:122-8.

13. Yanti, Pramudito TE, Nuriasari N, Juliana K. Lemon pepper fruit extract (Zanthoxylum acanthopodium DC) suppresses the expression of inflammatory mediators in lipopolysaccharideinduces macrophages in vitro. Am J Biochem Biotech. 2011; 7(4):190-5.

14. Bahuguna A, Khan I, Bajpai VK, Kang SC. MTT assay to evaluate the cytotoxic potential of a drug. Bangladesh $\mathbf{J}$ Pharmacol. 2017;12(2):115-8.

15. Van Linthout S, Miteva K, Tschöpe C. Crosstalk between fibroblasts and inflammatory cells. Cardiovasc Res. 2014;102(2): 258-69.

16. Nilforoushzadeh MA, Ashtiani HRA, Jaffary F, Jahangiri F, Nikkhah N, Mahmoudbeyk M, et al. Dermal fibroblast cells: Biology and function in skin regeneration. J Skin Stem Cell. 2017;4:1-5.

17. Indonesia DK. Parameter standar umum ekstrak tumbuhan obat. General standard parameters of medicinal plant extracts. Jakarta: Departemen Kesehatan Republik Indonesia; 2000. p. 9-12.

18. Widyarman AS, Drestia AM, Bachtiar EW, Bachtiar BM. The anti-inflammatory effects of glycerol-supplemented probiotic Lactobacillus reuteri on infected epithelial cells in vitro. Contemp Clin Dent. 2018;9(2):298-303.

19. Kristanty RE, Suriawati J. The Indonesian Zanthoxylum acanthopodium DC.: Chemical and Biological Values. Int J PharmTech Res. 2015;8(6):313-21.

20. Wijaya CH, Napitupulu FI, Karnady V, Indariani S. A review of the bioactivity and flavor properties of the exotic spice "andaliman" (Zanthoxylum acanthopodium DC.). Food Rev Int. 2018;35(1):1-19.

21. Aslantürk ÖS. In vitro cytotoxicity and cell viability assays: Principles, advantages, and disadvantages. In: Larramendy ML, Soloneski S, editors. Genotoxicity-A predictable risk to our actual world. London: InTechOpen; 2018. p. 1-19.

22. van Tonder JJ. Development of an in vitro mechanistic toxicity screening model using cultured hepatocytes. Ph.D. [dissertation]. Pretoria: University of Pretoria; 2011.

23. Matsuura HN, Fett-Neto AG. Plant alkaloids: Main features, toxicity, and mechanisms of action. In: Gopalakrishnakone P, Carlini CR, Ligabue-Braun R, editors. Plant Toxins. Dordrecht: Springer; 2015. p. 1-15.

24. Satria D, Silalahi J, Haro G, Ilyas S, Hasibuan PAZ. Cell cycle inhibition of ethylacetate fraction of Zanthoxylum acanthopodium DC. fruit against T47D cells. Maced J Med Sci. 2019; 7(5):726-9.

25. Kumar V, Robbins SL. Robbins basic pathology. Philadelphia: Saunders-Elsevier; 2007. p. 31

26. Guo S, Dipietro LA. Factors affecting wound healing. J Dent Res. 2010;89(3):219-29.

27. Velnar T, Bailey T, Smrkolj V. The wound healing process: An overview of the cellular and molecular mechanisms. J Inter Med Res. 2009;37(5):1528-42.

28. Basso FG, Pansani TN, Turrioni APS, Soares DG, De Souza Costa CA, Hebling J. Tumor necrosis factor- $\alpha$ and interleukin (IL)- $1 \beta$, IL-6, and IL-8 impair in vitro migration and induce apoptosis of gingival fibroblasts and epithelial cells, delaying wound healing. J Periodontol. 2016;87(8):990-6.

29. Rathee P, Chaudhary H, Rathee S, Rathee D, Kumar V, Kohli $\mathrm{K}$. Mechanism of action of flavonoids as anti-inflammatory agents: A review. Inflamm Allergy Drug Targets. 2009;8(3): 229-35.

30. Park M, Cho H, Jung H, Lee H, Hwang KT. Antioxidant and anti-inflammatory activities of tannin fraction of the extract from black raspberry seeds compared to grape seeds. J Food Biochem. 2014:38(3):259-70. 